\title{
Pengaruh Store Atmosphere, Social Media Promotion, Word Of Mouth Terhadap Keputusan Pembelian Di Habbit Eatery Coffee Malang
}

\author{
Mariana Puspa Dewi \\ Institut Teknologi dan Bisnis Asia Malang, Indonesia ${ }^{1,2}$
}

$\checkmark$ Corresponding Author:

\section{Nama Penulis: Mariana Puspa Dewi}

E-mail: mariana@asia.ac.id

\begin{abstract}
This research aims to find out and explain the effect of store atmosphere, promotion on social media and word of mouth on consumer purchasing decisions at the Habbit Eatery Coffee either partially or simultaneously. This research uses a quantitative approach. The sample of this study were 100 consumers of cafe omah root using non probability sampling method and accidental sampling technique. The instrument of this study uses a questionnaire and analyzed using multiple linear regression analysis. The results of this study indicate that store atmosphere partially has no effect on purchasing decisions, promotion on social media and word of mouth partially has a positive and significant effect on purchasing decisions. Simultaneously, store atmosphere, promotion on social media and word of mouth has a positive and significant effect on purchasing decisions.
\end{abstract}

Keywords: Store Atmosphere; Social Media Promotion; Word of Mouth; Purchasing Decisions

Abstrak: Penelitian ini bertujuan untuk mengetahui dan menjelaskan pengaruh store atmosphere, social media promotion dan word of mouth terhadap keputusan pembelian konsumen di Habbit Eatery Coffee baik secara parsial ataupun simultan. Penelitian ini menggunakan pendekatan kuantitatif. Sampel penelitian ini adalah 100 konsumen Habbit Eatery Coffee dengan menggunakan metode non probability sampling serta teknik accidental sampling. Instrumen penelitian ini menggunakan kuesioner dan dianalisis menggunakan analisis regresi linier berganda. Hasil penelitian ini menunjukkan bahwa store atmosphere secara parsial tidak berpengaruh terhadap keputusan pembelian, promosi di media sosial dan word of mouth secara parsial berpengaruh positif dan signifikan terhadap keputusan pembelian. Secara simultan store atmosphere, promosi di media sosial dan word of mouth berpengaruh positif dan signifikan terhadap keputusan pembelian.

Kata Kunci: Store Atmosphere; Social Media Promotion; Word of Mouth; Keputusan Pembelian 


\section{PENDAHULUAN}

Dunia bisnis terus berkembang pesat sejalan dengan perkembangan era globalisasi, hal ini ditandai dengan semakin ketatnya tingkat persaingan dalam memasarkan produk maupun jasa kepada konsumen. Persaingan yang ketat menuntut para pengusaha untuk dapat menentukan strategi yang tepat dalam berkompetisi. Pengusaha dituntut untuk memahami perilaku konsumen pada target pasarnya. Perilaku konsumen adalah suatu proses yang dilalui oleh konsumen dalam mencari, membeli, menggunakan, mengevaluasi demi memenuhi kebutuhan dan keinginannya. Perilaku konsumen berbeda - beda karena banyak hal yang mendasari, baik dari dalam diri sendiri maupun pengaruh dari luar. Kebutuhan dan keinginan konsumen selalu menjadi perhatian utama bagi pemilik usaha, karena dapat dijadikan dasar analisa perilaku konsumennya. Oleh sebab itu suatu perusahaan dituntut untuk memperhatikan perilaku konsumen dan menyesuaikan produknya dengan kebutuhan konsumen.

Pengambilan keputusan merupakan suatu kegiatan individu yang secara langsung terlibat dalam pembelian dan penggunaan barang yang ditawarkan. Tingkat pembelian yang tinggi akan berdampak pada tingginya volume penjualan, sehingga keuntungan yang akan didapat oleh perusahaan semakin tinggi. Melihat kondisi ini perlu adanya segmentasi pasar. Segmentasi pasar pada Habbit Eatery Coffee yaitu pelajar, mahasiswa dan eksekutif muda karena pada usia ini adalah usia yang sangat mengikuti gaya hidup dan trend. Penelitian ini dilakukan di kota Malang sebagai kota pelajar yang didominasi pelajar / mahasiswa. Selain pelajar, sebagian besar pengunjung Habbit Eatery Coffee juga eksekutif muda (Esmud). Hal ini dikarenakan para eksekutif muda (Esmud) membutuhkan tempat untuk santai sejenak dari rutinitas dan kepadatan pekerjaan sehari - hari, sembari menyelesaikan pekerjaan ringan dan bahkan ber-negosiasi dengan klien. Oleh karenanya harus ada strategi untuk memenangkan persaingan dengan menyediakan tempat yang nyaman untuk konsumen agar betah ketika berkunjung ke Habbit Eatery Coffee dan melakukan pembelian.

Banyak faktor yang dapat mempengaruhi keputusan pembelian seperti store atmosphere, social media promotion dan word of mouth. Store Atmosphere (suasana café) yaitu menciptakan keadaan di dalam café. Suasana café, penggunaaan musik, 
pencahayaan, bentuk penyajian minuman maupun makanan yang menarik dapat membuat psikologis konsumen yang tadinya stress karena aktivitas yang padat menjadi rileks, santai dan terhibur dengan nuansa café tersebut.

Promosi di Media Sosial. Promosi adalah salah satu cara untuk mengenalkan usaha atau produk kepada konsumen. Promosi jaman sekarang tidak dilakukan dengan menyebarkan brosur tetapi dengan mengunggah konten foto, video, caption menarik di media sosial. Kemajuan teknologi penggunaan media sosial dalam bidang pemasaran bisnis tak luput dari perhatian para pebisnis. Media sosial yang trend saat ini yaitu Instagram dan Facebook. Instagram dan Facebook dipilih sebagai media promosi yang paling diandalkan karena tidak memiliki batasan jumlah karakter tulisan, bisa memuat foto, video dan jangkauannya luas. Habbit Eatery Coffee memilih Instagram dan Facebook sebagai media pemasaran mereka. Store atmosphere dan promosi di media sosial merupakan faktor yang penting dalam penentuan keputusan pembelian. Namun, ada juga promosi yang secara tidak langsung dilakukan oleh konsumen Ketika konsumen merasakan sebuah kepuasan dari store atmosphere dan promosi di media social maka konsumen melakukan sebuah promosi yang disebut Word of Mouth (dari mulut ke mulut). Word of mouth merupakan salah satu bentuk promosi yang dilakukan konsumen ke calon konsumen yang lain serta dilakukan dengan cara bercerita akan kepuasan tentang sebuah produk. Store atmosphere, promosi di media sosial dan word of mouth merupakan bagian dari strategi pemasaran mempunyai peran penting yang mampu mempengaruhi keputusan pembelian.

Penelitian terdahulu yang telah dilakukan oleh (Pamungkas, Bagas Aji \& Zuhroh, 2017) menemukan bahwa promosi di media sosial dan word of mouth berpengaruh positif terhadap keputusan pembelian di Kedai Bontacos, Jombang, sama dengan penelitan yang dilakukan oleh (Diyatma, 2017) yang mengatakan bahwa promosi melalui media sosial berpengaruh positif terhadap keputusan pembelian produk di Saka Bistro dan Bar. Berbeda dengan penelitian yang dilakukan oleh (Wulansari, Esti \& Sudarwanto, 2014) yang mengatakan bahwa store atmosphere berpengaruh positif terhadap keputusan pembelian pada Pos Shop Coffee Toffee Simpang, sama dengan penelitian yang dilakukan (Romadhon, 2017) yang mengatakan bahwa store atmosphere dan word of mouth berpengaruh signifikan dan positif terhadap 
keputusan pembelian pada Café Kolong Jember, sama dengan penelitian (Nugraha, 2015) yang mengatakan bahwa word of mouth memiliki pengaruh positif secara simultan terhadap keputusan pembelian di Café Roti Gempol dan Kopi Anjis.

Dari riset gap terdahulu, maka penulis tertarik untuk melakukan penelitian ini untuk mengetahui dan menguji model pengaruh store atmosphere, promosi di media sosial dan word of mouth terhadap keputusan pembelian di Habbit Eatery Coffee Malang.

\section{METODE PENELITIAN}

Penelitian ini bertujuan untuk mengetahui dan menguji model pengaruh store atmosphere, promosi di media sosial dan word of mouth terhadap keputusan pembelian di Habbit Eatery Coffee Malang. Jenis penelitian yang digunakan adalah riset kausal yaitu penelitian yang bersifat sebab akibat, yang bertujuan untuk mengetahui variabel mana yang menjadi penyebab dan variabel yang dipengaruhi. Dalam penelitian ini variabel Store Atmosphere, Promosi di Media Sosial dan Word of Mouth dijadikan sebagai sebab yang memberikan akibat pada variabel keputusan pembelian Habbit Eatery Coffee. Jenis data yang digunakan dalam penelitian ini berupa data angka atau kuantitatif yang berasal dari analisis kuesioner. Tehnik pengambilan sampel yang digunakan dalam penelitian ini adalah melalui pendekatan non probability sampling. Dengan menggunakan teknik Accidental sampling. jumlah sampel yang digunakan dalam penelitian ini berjumlah 100 responden yang terdiri dari konsumen yang melakukan pembelian baik pembelian pertama kali ataupun repeat order.

Dalam penelitian ini, peneliti mengunakan kuisioner yang terstruktur, dengan menggunakan skala likert. Caranya adalah dengan memberikan daftar pertanyaan pada responden sebagai alat untuk pengumpulan data atau informasi dari responden. Skala pengukuran atas jawaban pertanyaan - pertanyaan dengan menggunakan skala likert yang dilambangkan dari skor 1 sampai dengan 5. Pemeringkatan skala likert nampak pada tabel dibawah ini:

Tabel 2.1 Pemeringkatan Skala Likert

\begin{tabular}{clcc}
\hline No & \multicolumn{1}{c}{ Jawaban } & Notasi & Nilai Skor \\
\hline 1 & Sangat Setuju & SS & 5 \\
\hline 2 & Setuju & S & 4 \\
\hline
\end{tabular}




\begin{tabular}{llcl}
\hline 3 & Netral & N & 3 \\
\hline 4 & Tidak Setuju & TS & 2 \\
\hline 5 & Sangat Tidak Setuju & STS & 1 \\
\hline
\end{tabular}

Menurut (Arikunto, 2006), hipotesis merupakan jawaban yang bersifat sementara terhadap permasalahan penelitian sampai terbukti melalui data yang terkumpul. Dengan mengacu rumusan masalah, landasan teori, dan kerangka pemikiran tersebut, maka hipotesis yang diajukan dalam penelitian ini adalah sebagai berikut: H1 : Diduga Store Atmosphere memiliki pengaruh secara parsial terhadap keputusan pembelian pada Habbit Eatery Coffee

H2 : Diduga Promosi di media Sosial memiliki pengaruh secara parsial terhadap keputusan pembelian pada Habbit Eatery Coffee.

H3 : Diduga Word of Mouth memiliki pengaruh secara parsial terhadap keputusan pembelian pada Habbit Eatery Coffee.

H4 : Diduga Store Atmosphere, Promosi di Media Sosial dan Word of Mouth berpengaruh secara simultan terhadap keputusan pembelian pada Habbit Eatery Coffee.

\section{HASIL PENELITIAN}

\subsection{Uji Validitas}

Menurut (Arikunto, 2006) validitas adalah suatu ukuran yang menunjukkan tingkat - tingkat kevalidan atau kesahihan sesuatu instrument. Pengujian validitas ini menggunakan Pearson Correlation yaitu dengan cara menghitung korelasi antar skor masing - masing butir pertanyaan dengan total skor. Jika korelasi antar skor masing - masing butir pertanyaan dengan total skor mempunyai tingkat signifikansi 0,05 maka pertanyaan tersebut dinyatakan valid dan sebaliknya.

\subsection{Uji Reliabilitas}

Reliabilitas adalah suatu instrument yang cukup dapat dipercaya untuk digunakan sebagai alat pengumpul data karena instrument tersebut sudah baik, sehingga mampu mengungkap data yang bisa dipercaya. Rumus yang digunakan untuk mencari reliabilitas yang berbentuk angket atau kuesioner adalah rumus Alpha (Arikunto, 2006), dengan ketentuan sebagai berikut:

a) Jika koefisien alpha $(\alpha)<0,60$ maka butir pertanyaan dinyatakan tidak reliabel. 
b) Jika koefisien alpha $(\alpha)>0,60$ maka butir pertanyaan dinyatakan reliabel.

\subsection{Uji T}

Uji t digunakan untuk menguji apakah variabel independen secara parsial berpengaruh terhadap variabel dependen. Langkah - langkah uji t:
a) Menentukan hipotesis statistik
b) Menentukan signifikan
c) Perhitungan nilai t
d) Menentukan hasil pengujian
e) Kesimpulan untuk menolak atau menerima HO tergantung dari bentuk perumusan hipotesisnya, yaitu sebagai berikut:

\section{Gambar 2.1 Kurva Pengambilan Keputusan Uji t-Statistik}

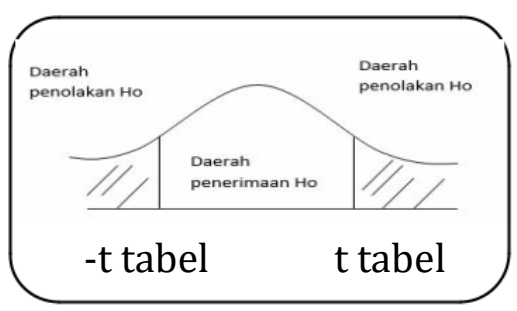

\subsection{Uji F}

Sumber Data : Sugiyono, 2011

Uji F adalah pengujian yang digunakan untuk mengetahui kebenaran dari suatu hipotesis variabel independent (X) secara bersama - sama apakah dapat berpengaruh atau tidak terhadap variabel dependentnya (Y). Langkah langkah penentuan uji :
a. merumuskan hipotesis statistik
b. menentukan taraf nyata / level of significance $=a$
c. perhitungan nilai $\mathrm{f}$
d. menentukan pengambilan keputusan

Gambar 2.2 Kurva Pengambilan Keputusan Uji F-Statistik

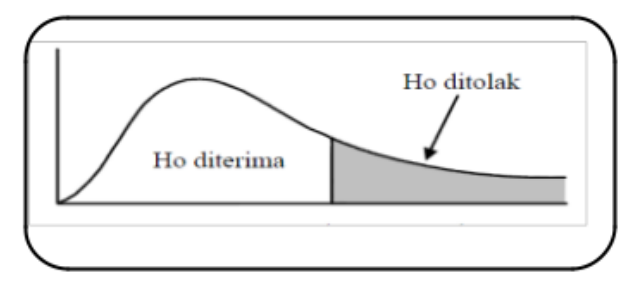

Sumber Data : (Sugiyono, 2016) 


\subsection{Uji R}

Koefisien determinasi $\left(\mathrm{R}^{2}\right)$ pada intinya mengukur seberapa jauh kemampuan model dalam menerangkan variabel dependen. Nilai koefisien determinasi adalah antara nol dan satu. Nilai $\mathrm{R}^{2}$ yang kecil berarti kemampuan variabel independen menjelaskan variabel dependen amat terbatas. Nilai yang mendekati satu berarti variabel - variabel independen memberikan hampir semua informasi yang dibutuhkan untuk memprediksi variasi variabel dependen.

\begin{tabular}{|l|c|r|r|r|r|}
\hline \multicolumn{7}{|c|}{ Model Summary } \\
\hline Model & $\mathbf{R}$ & $\begin{array}{c}\mathrm{R} \\
\text { Square }\end{array}$ & $\begin{array}{c}\text { Adjusted R } \\
\text { Square }\end{array}$ & $\begin{array}{r}\text { Std. Error of } \\
\text { the Estimate }\end{array}$ & $\begin{array}{r}\text { Durbin- } \\
\text { Watson }\end{array}$ \\
\hline $\mathbf{1}$ &, $778^{\mathrm{a}}$ &, 606 &, 601 & 1,30189 & 1,889 \\
\hline \multicolumn{5}{|l|}{ a. Predictors: (Constant), Word Of Mouth, Viral Marketing } \\
\hline
\end{tabular}

Sumber : Data Diolah Tahun 2021

Mengungkapkan nilai R Square yang diperoleh dari penelitian ini adalah 0.606. Nilai rsquare adalah 0,606 x $100=60,6 \%$. Kesimpulannya besarnya kontribusi X1 dan X2 terhadap Y secara simultan adalah 60,6\% dan selebihnya dipengaruhi oleh faktor lain yang belum dibahas dipenelitian ini sebesar 39,4\%.

\section{PEMBAHASAN}

Pada bagian ini akan dipaparkan pembahasan mengenai hasil analisis yang telah dilakukan oleh peneliti dimana hasil analisis mengacu pada hasil pengolahan data melalui uji instrument penelitian, uji asumsi klasik, analisis regresi linier berganda, koefisien determinasi $\left(\mathrm{R}^{2}\right)$, dan uji hipotesis dengan menggunakan SPSS ver.23.

\section{Pengujian Hipotesis}

Dari hasil uji t diketahui bahwa variabel store atmosphere secara parsial tidak berpengaruh terhadap variabel keputusan pembelian, sedangkan variabel promosi di media sosial dan word of mouth secara parsial berpengaruh postif dan signifikan terhadap keputusan pembelian.

Hasil uji F menjelaskan bahwa variabel store atmosphere, promosi di media sosial dan word of mouth secara simultan berpengaruh positif dan signifikan terhadap variabel keputusan pembelian pada konsumen Habbit Eatery Coffee.

\section{Pengaruh Store Atmosphere (X1) Terhadap Keputusan Pembelian.}

Dari hasil perhitungan yang dilakukan oleh peneliti, hasil uji hipotesis 
menggunakan uji $\mathrm{t}$ menunjukkan nilai $\mathrm{t}$ hitung 1,468 $<\mathrm{t}$ table 1,988. Berdasarkan hasil analisis dapat disimpulkan bahwa store atmosphere (X1) tidak berpengaruh terhadap keputusan pembelian pada Habbit Eatery Coffee. Hal ini dikarenakan tanda informasi bagi konsumen yang kurang tepat seperti papan nama café yang penempatannya tidak tepat, lokasi tidak di jalan utama, dan tidak terlihat jelas. Lokasi ke Habbit Eatery Coffee yang relatif sulit dijangkau karena agak masuk dari jalan besar serta penataan meja yang kurang sesuai membuat konsumen merasa apa yang dibayangkan tidak sesuai dengan apa yang diperoleh, infrastruktur cafe juga belum memadai dikarenakan ada lokasi indoor dan outdoor dimana saat musim hujan, lokasi outdoor nyaris tidak bisa dipergunakan karena tidak ada atap pelindung ataupun payung besar untuk berlindung dari hujan. Meja yang digunakan di lokasi outdoor tidak dibersihkan kecuali pada saat ada pengunjung, sehingga saat pengunjung datang, pengunjung dapat melihat debu, patahan ranting dan daun kering di atas meja. Lokasi indoor juga agak sedikit remang-remang, dikarenakan penerangan menggunakan lampu kuning sehingga pencahayaan kurang terang. Hal ini yang menjadikan store atmosphere tidak berpengaruh terhadap keputusan pembelian. Meskipun banyak yang menjawab setuju dengan pernyataan bahwa Habbit Eatery Coffee unik, instagramable dan nyaman tetapi jika tidak diimbangi dengan kemudahan dalam menjangkau lokasi Habbit Eatery Coffee dan store atmosphere yang memadai maka tidak akan berpengaruh secara langsung terhadap keputusan pembelian.

\section{Pengaruh Promosi di Media Sosial (X2) Terhadap Keputusan Pembelian.}

Dari hasil perhitungan yang dilakukan oleh peneliti, hasil uji hipotesis menggunakan uji t menunjukkan nilai t hitung promosi di media sosial adalah 2,673 > t tabel 1,988. Berdasarkan hasil analisis dapat disimpulkan bahwa Promosi di Media Sosial (X2) berpengaruh secara positif dan signifikan terhadap keputusan pembelian pada Habbit Eatery Coffee. Dalam hal ini Habbit Eatery Coffee menggunakan media sosial sebagai media promosi karena dirasa sangat efektif dan efisien, serta peningkatan jumlah 
pengguna media sosial terus meningkat setiap tahun membuat informasi yang dibagikan di media sosial dapat terus menyebar lebih luas, Habbit Eatery Coffee juga dapat menjalin hubungan baik dengan konsumen melalui media sosial. Hal ini dapat dibuktikan dengan jawaban responden di kuisioner bahwa rata - rata responden menyatakan setuju dengan pernyataan yang diberikan peneliti.

\section{Pengaruh Word of Mouth (X3) Terhadap Keputusan Pembelian.}

Dari hasil perhitungan yang dilakukan oleh peneliti, hasil uji hipotesis menggunakan uji t menunjukkan nilai thitung word of mouth adalah 4,531 > ttabel 1,988. Berdasarkan hasil analisis dapat disimpulkan bahwa word of mouth (X3) berpengaruh secara positif dan signifikan terhadap keputusan pembelian pada Habbit Eatery Coffee. Dalam hal ini pembicaraan orang lain terhadap suatu produk menjadi bagian dari pertimbangan konsumen untuk memilih suatu produk. Evaluasi alternatif dilakukan konsumen pada saat akan melakukan keputusan pembelian dengan word of mouth paling menarik. Konsumen cenderung lebih mempercayai word of mouth communication dalam menilai sebuah produk dibandingkan iklan. Cerita dan pengalaman seseorang menggunakan sebuah produk terdengar lebih menarik yang bisa mempengaruhi pendengarnya untuk ikut mencoba produk tersebut. Hal ini dapat dibuktikan dengan jawaban responden di kuisioner bahwa rata - rata responden menyatakan setuju dengan pernyataan yang diberikan peneliti.

\section{Hasil Uji F}

Dari perhitungan yang dilakukan peneliti, hasil uji hipotesis menggunakan uji - f menunjukkan bahwa Fhitung 37,529 > Ftabel 2,70 atau tingkat signifikan F adalah $0,000<$ tingkat signifikan $\alpha=0,05$. Berdasarkan hasil analisis dapat disimpulkan bahwa ada pengaruh secara simultan antara store atmosphere, promosi di media sosial dan word of mouth terhadap keputusan pembelian. Artinya bahwa ada pengaruh secara bersama - sama (simultan) antara variabel store atmosphere, promosi di media social dan word of mouth terhadap keputusan pembelian pada konsumen Habbit Eatery Coffee. 


\section{KESIMPULAN}

Berdasarkan hasil penelitian yang telah dilakukan, maka dapat disimpulkan sebagai berikut:

1. Store Atmosphere tidak berpengaruh terhadap keputusan pembelian di Habbit Eatery Coffee. Baik dari segi indoor dan outdoor tidak mempengaruhi keberadaan konsumen.

2. Promosi di Media Sosial berpengaruh positif dan signifikan terhadap keputusan pembelian di Habbit Eatery Coffee, utamanya di Instagram, Facebook dan website.

3. Word of Mouth berpengaruh positif dan signifikan terhadap keputusan pembelian di Habbit Eatery Coffee. Kekuatan promosi lewat mulut menjadikan Habbit Eatery Coffee makin dikenal luas.

4. Store Atmosphere, Promosi di Media Sosial dan Word of Mouth secara bersama - sama berpengaruh positif dan signifikan terhadap keputusan pembelian di Habbit Eatery Coffee.

\section{REFERENSI}

Arikunto, S. (2006). Prosedur Penelitian : Suatu Pendekatan Praktek / Suharsimi Arikunto. In Rineka Cipta (Vol. 2006, Issue 2006). PT Rineka Cipta. http://library.um.ac.id/free-contents/index.php/buku/detail/prosedurpenelitian-suatu-pendekatan-praktek-suharsimi-arikunto-19157.html

Berry Berman dan Joel R. Evans. (2013). Retail Management: A Strategic Approach. Pierson.

Diyatma, A. J. (2017). Pengaruh Promosi Melalui Media Sosial Instagram Terhadap Keputusan Pembelian Produk Saka Bistro dan Bar. Manajemen: Fakultas Ekonomi Dan Bisnis, Universitas Telkom, Vol. 4, No. 1, April 2017, Hal 175-179., 4(1), 175-179.

Ghozali, I. (2005). Aplikasi Analisis Multivariate dengan Program SPSS. Badan Penerbit Universitas Diponegoro.

Hasan, M. I. (2002). Pokok-pokok Materi Metodologi Penelitian dan Aplikasinya. Ghalia Indonesia.

Kotler, P. \& G. A. (2010). Prinsip-Prinsip Pemasaran, Jilid 1 dan 2 (12th ed.). Erlangga. Nugraha, D. E. P. (2015). Pengaruh Word of Mouth Terhadap Keputusan Pembelian pada Café Roti Gempol dan Kopi Anjis. Administrasi Bisnis: Fakultas Komunikasi Dan Bisnis, Universitas Telkom, 2(1), 758-763.

Pamungkas, Bagas Aji \& Zuhroh, S. (2017). Pengaruh Promosi di Media Sosial dan Word of Mouth Terhadap Keputusan Pembelian (Studi Kasus pada Kedai Bontacos, Jombang),. Universitas Trunojoyo Madura, 10(2).

Romadhon, A. P. (2017). PENGARUH STORE ATMOSPHERE, HARGA, DAN WORD OF MOUTH TERHADAP KEPUTUSAN PEMBELIAN (Studi Pada Cafe Kolong Jember). Repository Universitas Jember. 
Solis, B. (2011). Engage: The Complete Guide for Brands and Businesses to Build, Cultivate.

Sugiyono. (2016). Metode Penelitian Pendidikan. Bandung. In Metode Penelitian Pendidikan (Pendekatan Kuantitatif, Kualitatif, dan R\&D). Alphabeta.

Sumardi. (2009). Word of Mouth Marketing, Fans dan Peluang Tumbuh. SWA, 08/XXV/16-29 April.

Swastha, B. (2007). Manajemen Pemasaran Modern.

Tjiptono, F. (2008). Strategi Pemasaran, Edisi III, Yogyakarta : CV. Andi Offset.

Wulansari, Esti \& Sudarwanto, T. (2014). Pengaruh Café Atmosphere dan Harga Terhadap Keputusan Pembelian pada Pos Shop Coffee Toffe Simpang. Ekonomi: Universitas Negeri Surabaya. 